\title{
ON THE REASONS FOR THE PRESENCE OF KITSCH IN CONTEMPORARY RELIGIOUS SPACE
}

\author{
BEATA SKRZYDLEWSKA
}

Faculty of Humanities,

Cardinal Stefan Wyszyński University in Warsaw

b.skrzydlewska@uksw.edu.pl

The main aim of this study is to try to identify the sources of the phenomenon of kitsch in contemporary religious art in Poland. I will not analyze the notion of kitsch or other aspects of this problem. The following considerations will be presented from the point of view of a person who has been scientifically and practically engaged in the protection of religious art monuments for years. Observations made during the implementation of projects for church museums, providing advice on the protection of monuments ${ }^{1}$, as well as didactic work as a lecturer of art history in clerical seminaries prompted me

1 Preparation and implementation, together with Elżbieta Kasprzak (Techne Group), of projects for museums: Museum of the 200th Anniversary of the Lublin Diocese in Lublin (2007), Diocesan Museum in Łowicz (2011), implementation of the 'Museum in the Tower' in the Rector's Church of the Assumption of the Blessed Virgin Mary (pobrygidkowski) in Lublin (2012), Museum at the Roman Catholic Parish of St. Wojciech in Wawolnica (2012); projects of museums realized with another contractor: the concept of the educational path Monastery in the heart of the city - scenario and arrangement of the educational path (2012), the project of the exhibition in the crypts of the Church of Finding the Holy Cross and St. Andrew the Apostle in Końskowola (2011); projects not realized so far due to lack of funds: the Ignacy Konarski Museum at the Roman Catholic Parish of the Assumption of the Blessed Virgin Mary in Opole Lubelskie, arrangement of the museum exhibition related to the history of the parish and the town of Końskowola, scenario and design of the permanent exhibition - Monastery of the Capuchin Friars Minor in Lublin. 
to reflect on the level of Polish sacred art and its significance for the reception of the message of the Church.

The activity in the area of the protection of religious art monuments poses certain problems for the employees participating in the process of developing the church space. They often ask themselves questions about the reason for the emergence and spread of kitsch in this domain. Why, despite the rich tradition of the Roman Catholic Church in the field of construction, collecting works of art and creating exhibitions, is there so much kitsch in the churches? What is more, why is it so that wonderful works of art, which are an unrivalled model for contemporary artists and have been a source of admiration for many generations, often provide only a background for objects which do not represent any artistic value at all?

More and more often churches and sanctuaries are filled with objects which, although pretend to be works of art, do not have a proper aesthetic value. They are technically unprofessional, and their religious message is trivial, affectionate and, worst of all, even false, as it reduces and deforms the truth of the faith.

How does it happen that such products occupy sacral space? Is it to attract the faithful that popular tastes are being flattered? Or maybe the buyer is tempted by their availability or their relatively low price?

The problem is multi-faceted, it is difficult to give a concise and unambiguous answer to the above questions. While communing with great or at least good art requires a certain knowledge of artistic culture from an ordinary recipient, priests who are guardians of churches, and often investors and patrons, should be required to have a thorough education in art history, if only to avoid making the church space a place for gathering poor or kitschy art.

I am not analyzing specific objects, worthless creations of plastic art or misguided sacral architecture, but I am trying to explain the reasons for the presence of kitsch in the contemporary church space, based on examples of actions resulting from the decisions of specific people or institutions.

As the problem is very broad, I do not want to elaborate on the issue of crisis in art - including church and religious art - which has its ideological basis in certain philosophical currents (e.g. postmodernism or any concepts that instrumentalise art and reduce it to ideological and utopian purposes) or theological ones. This phenomenon, although it has influenced the perception 
of works of art, lies primarily in the field of research of cultural philosophers ${ }^{2}$. Let me just mention, however, that the result of the crisis is not only the fact that art has become a field of experimentation, but also subjecting artistic creation to various ideologies that ultimately prevent it from achieving its proper goal, namely catharsis. In other words, the consequence of the crisis of art seems to be a departure from the categories of truth, goodness and beauty. Unfortunately, this departure is also accompanied by the violation of certain rules present in art so far, but above all by the betrayal of the proper purpose of art, which is to improve human beings. Kitsch is also present in religious and sacral art. It is therefore important to find an answer to the question about the reasons for this state of affairs.

Many reasons can be mentioned here, including the lack of proper education of the clergy, ignorance of the law and of the guidelines of the Roman Catholic Church concerning art in the sacred space. Thus, the evil of kitsch has its root not so much in the lack of aesthetic sensitivity, as in the departure of sacred art from its classical character.

\section{THE PRESENCE OF KITSCH IN THE CHURCH SPACE}

When analyzing the phenomenon of kitsch in the context of sacral art, we often concern ourselves with the reasons for its presence, yet less frequently with its influence on the recipient ${ }^{3}$. And the latter should be considered, as kitsch, once it appears, gradually makes us accustomed to its presence and, imperceptibly, causes enormous devastation in the area of cognition and religious life. This kind of 'art' certainly does not affect the minds of believers in any positive way.

At this point it is worth referring to the words of Plutarch, who, in his reflections on upbringing, posed the question of how to skillfully use the works of the poets. He drew the conclusion that 'reading is food that

2 The issue of the crisis in art was raised e.g. in the works of representatives of the Lublin School of Philosophy. See: Jaroszyński 1986, 1992; Kiereś 1993, 1996, 1996, 2004.

3 Numerous attempts have been made to define the concept of kitsch, and many studies have been devoted to this issue, such as: Banach 1968; Rożek (ed.) 2000 . 
gives health, but may bring about mental 'un-health' when used wrongly' (Majchrowicz 1922: 27).

Travestying this quote for our needs, we can say that art is the food that gives health, but it may be 'un-health' when used wrongly. Kitsch deceives us, communicates the truth - in this case: religious truth - in a shallow form. We can agree with Ryszard Knapiński's statement that 'kitsch is a product of a man that responds to the need to experience beauty, but fails to satisfy it, and hence remains an incomplete, superficial, and in a broad sense unfinished work' (Knapiński 2004: 111). The question arises as to why is sacral space filled with 'works' through which artists want to convey more than they actually can, whether regarding their technical skills, talent or religious knowledge. Why is there so much interest in this kind of 'products'? (I am deliberately avoiding to use the term 'works of art')?

One of the reasons may be the lack of knowledge from various spheres. The reception of a real work of art is not easy, it requires sensitivity, but above all erudition, which leads to deeper reflection. Indulging in kitsch is also the effect of laziness (Kłoczowski 2003). Thinking about art and the message it conveys requires commitment, while contemporary mass culture does not require people to think, it often results from cognitive mistakes, and sometimes is accompanied by an ideology standing in contradiction to the Revelation. Just like in fast food restaurants, where we get a readymade, nicely packaged product - yet, unhealthy and of little value - in the case of art, there is also a danger and some kind of evil, which should never be present (especially in religious art, which by definition, is destined for the highest matters, that is, concerning God, the knowledge of God, His love and eternal life with Him). This kind of 'art' triggers emotions and is understood manically, i.e. only as an area of emotional experience. And since everyone has different experiences, perhaps the guardian of the church, in order to respond to the feelings experienced by the faithful, sees no reason to remove these trashy objects from the sacral space. Meanwhile, art is materialized cognition and materialized love ${ }^{4}$. The one who introduces

4 See: Kiereś 2008: 310-312. As Kiereś observes: 'Art is a field of human activity and together with science, morality and religion it co-creates culture. Art emerges from a productive (poetic) cognition and either supports the forces of nature in achieving its proper goal, e.g. in breeding animals or medicine, or 
it into the sacred space should make sure that it is a high-ranking art, proportionally related both to the recipient (the believer) and to the reality of God, trying to present Him to present to man. Religious art leads to God, and kitsch definitely hinders its message.

Commerciality is particularly conducive to kitsch. The great availability of cheap products satisfies the tastes of average recipients. On the occasion of indulgence feasts, beatifications, canonizations or pilgrimages to sanctuaries, most of the participants buy devotional items produced in a careless manner and not representing any artistic value. The Sacral Fair 'Sacroexpo' held annually in Kielce (the second largest fair of this kind in Europe) is a paradise for exhibitors and buyers.

The organizers of the event should be given justice - they try to appreciate real art. The fair is always accompanied by conferences on contemporary sacral architecture and religious museums ${ }^{5}$. The symposiums aim to show the proper way in the field of designing new churches and religious museums,

transposes the principles of nature's operation into creations, e.g. in construction or music. Nature is based on movement and change, and the first attribute of its dynamism is purposefulness. Art imitates nature (ars imitatur naturam), i.e. it creates intentionally, analogically to the purposefulness of nature; the artist decides about what and how to produce. The final reason (cause) for the existence of art is to fill the voids experienced by man in the world (ars supplet defectum naturae). Deficiencies appear in concrete beings: the 'defective' being does not have any perfection or integrating component to which it is entitled by virtue of its nature, e.g. health is perfection, and disease is the lack of perfection, thus: disease is the raison d'être of medicine. What is possible for nature, but what nature cannot produce without the participation of art (e.g. a house or a poem) is also an example of lack. The sole purpose of art is the good of man (omnes artes ordinantur ad hominis perfectionem), and the good of man is his own life. It is both given and inflicted on man (man is a potentialized entity), and it is a unity of three orders: vegetation, sensual and emotional life as well as intellectual and volitional (personal) life. Thus, art achieves proportionally 3 goals: it secures growth, disciplines the senses and feelings, thinking and acting, and updates the intellect and will of man' (ibid.: 310-311).

${ }^{5}$ In 2016, in cooperation with the Świętokrzyski University of Technology, the fifteenth conference on architecture was organized under the name Contemporary Sacral Architecture. Poland-Ukraine, as well as the $9^{\text {th }}$ International 
as well as to raise awareness of the problems related to modern trends in art. Although the conferences are open, despite the large number of visitors (in 2016 it was about five thousand people), the conference rooms are usually only attended by a handful of listeners in addition to the speakers themselves.

To draw attention to what is really beautiful and valuable, awards are given to artists engaged in religious art: the Medal of the Pontifical Council for Culture 'Per Artem ad Deum' for outstanding artists engaged in sacred art, the Honorary Medal of the Primate of Poland, Archbishop Wojciech Polak (this year the award was given to sister Natanela Wiesława Błażejczyk CSSF, graduate of the Academy of Fine Arts in Warsaw, for a creative approach in the sculptural representation of the Way of the Cross) or the Honorary Award of the Bishop of Kielce Fr. Jan Piotrkowski (in 2016 the award received by Maciej Trocewicz's Studio Prata for the vestment with the image of the Black Madonna, combining traditional embroidery with contemporary utility embroidery).

The fair is accompanied by exhibitions of old and contemporary art, as well as trainings and workshops for lay artists and priests. However, all this disappears in the thicket of ubiquitous rubbish. As it was noted in the commentary summarizing the $17^{\text {th }}$ Sacral Fair 'Sacroexpo', there is 'everything that the soul desires. A lot of business, a bit of art'.

There is actually less and less real art from year to year. It simply fails to find buyers and it is not a matter of exorbitant prices, but rather of tastes. What is readily bought are images of saints, tacky vestments, altars, which do not present any artistic value and are often exhibited in a cheap way.

I will now return to the question posed at the beginning: why is kitsch present in the contemporary church space? I will repeat - in my opinion, the main reason for the presence of kitsch is first of all the lack of proper education among the clergy, as well as ignorance of the guidelines of the Roman Catholic Church related to sacred art, combined with the lack of willingness to deepen one's knowledge in this field.

Conference of Museologists Museums of Our Times, concerning the problems of contemporary church museology.

${ }^{6} \mathrm{http}: / /$ www.targikielce.pl/pl/sacroexpo.htm [accessed: 25.09.2019]. 


\section{ON THE NEED FOR EDUCATION IN THE FIELD OF ART HISTORY - LEGAL GUIDELINES OF THE ROMAN CATHOLIC CHURCH}

In its teachings, the Church does not ignore the problem of sacred art and provides appropriate tools, in the form of legal documents, to prepare priests in this field (see: Leszczyński 2006, 2008; Skrzydlewska 1997, 2002). For centuries, the Holy See has been formulating acts concerning the protection of monuments, and most of them have a universal character and are valid in the whole Roman Catholic Church. The only question that remains is to what extent are the guidelines contained in these documents implemented. And even if they are implemented, it seems that sometimes it is done only perfunctorily. An example could be, the issue of educating future priests in the field of art history and the protection of historical monuments.

Already in 1907, Pope Pius X in Apostolicae Sedis issued a decree in which he ordered the inclusion of lectures on Christian archaeology and art history in the curriculum of clerical seminaries (see: Mariani 1945). Understanding the value of teaching this discipline, the Second Vatican Council (1961, art. 129) maintained that decision: 'During their philosophical and theological studies, clerics are to be taught about the history and development of sacred art, and about the sound principles governing the production of its works. In consequence they will be able to appreciate and preserve the Church's venerable monuments, and be in a position to aid, by good advice, artists who are engaged in producing works of art'.

Adapting to the Council's decisions, in 1973 the Polish Episcopal Conference published The Standards of Conduct in Matters of Ecclesiastical Art. According to this document, the task of the Commission for Ecclesiastical Art (created by the Polish Episcopal Conference) is to 'postulate curricula in Theological Seminaries on religious art and the protection of monuments' (Normy postepowania 1994: 301-306). The Standards... also mention that the Episcopal Commission should present 'ideas of educating priests, nuns and lay people in the field of Christian artistic culture'. Priests from different dioceses, sometimes from different religious orders (as well as nuns, from time to time), are regularly sent to specialization courses in this field, yet, this concerns only a small percentage of the clergy.

The last document issued in this respect - The Acts of the Ecumenical Council - was created after the Second Polish Plenary Synod convened 
on June $8^{\text {th }} 1991$, and ceremonially opened by Pope John Paul II (Ochrona $i$ konserwacja 2001: 117-119). According to one of the articles of the document, the responsibility for the protection of cultural goods rests primarily with parish priests and rectors of churches. In order to hold such a responsible function in a professional manner, priests are obliged to have basic knowledge of art history and historical studies during their seminary studies. The seminary course also includes classes in the conservation of church art: 'These should be extended to include visits to restoration workshops in order to make the alumni aware of the complexity and cost of specialist treatments, which would often not be necessary, had the principles of monument protection been observed' (ibid.: 68).

When deciding on works of art, bishops must seek advice from the Commission for Ecclesiastical Art, as well as from experts in history, art history and protection of monuments. An unprecedented issue raised in The Standards... was the idea to 'establish schools or academies of ecclesiastical art in those countries where it is necessary' (ibid.: 69).

The above mentioned documents indicate the direction for the education of future art guardians. Unfortunately, these regulations remain to a large extent nothing but guidelines. My observations as an art history lecturer in clerical seminaries are not optimistic. Approximately thirty hours are planned for art history classes within the six-year teaching course 7 . Taking into account the fact that $99 \%$ of the alumni do not have basic knowledge in this area, it is necessary to focus the lectures only on the main topics. Therefore, it is not easy to elaborate on issues related to the protection of cultural goods, when it is difficult for the listener to understand why he should take care of something whose value he remains ignorant of. During such a short course it is difficult to sensitize future priests to beauty and to teach them how to distinguish real art from ordinary rubbish. Moreover, clerics who come from different backgrounds, are usually accustomed to mass culture and are generally unable to see which objects are made of unsuitable materials, what are their technical shortcomings, whether they convey real content or just 'pretend' and are in fact an illusion of something

7 The range of hours varies slightly depending on the rectors' decisions. Timetables are included on the pages of individual seminaries for comparison. 
else, i.e. kitsch. This is highly disturbing as the kitsch filling the sacral space is like 'cancer on the body of art' (Osęka 1978; Mikeska 2008).

Further education should take place through regular studies in the field of history of art or protection of monuments, and only few priests are delegated to such courses. As a result, only individuals receive education in this field ${ }^{8}$. An important role can be played by occasional lectures organized by dioceses, meetings with artists and monument protection officers. Although there appear initiatives to meet these needs, apart from directors of church museums or chairmen of church art commissions, priests rarely participate.

\section{A WORK OF SACRED ART - LEGAL GUIDELINES}

Legal acts formulated by the Roman Catholic Church draw attention to issues related to the equipment of churches. These documents draw a clear line between what can be called a work of art and what we call trash. The main premise is to strive for aesthetic harmony, because only such harmony is conducive to concentration and directs our thoughts towards transcendent matters.

For example, the following works should not be present in churches, '(...) works which are not in conformity with faith and good manners and Christian piety, or offend the religious idea, either because of their inadequate form, or because of their poor level, mediocrity or imitation' (Second Vatican Council 1986: art. 124). In a church, the faithful should seek truth, goodness and beauty; true beauty, not false beauty, because false beauty is kitsch. Temples are sometimes a place of great stylistic diversity. Many of them were built in bygone eras, but due to the fact that they functioned continuously for several centuries, they were being filled with objects characteristic of each passing epoch. As these works conveyed the truth in a beautiful way, they are also admired and understood by the contemporary recipient of art.

Every few centuries there are certain breakthroughs in the history of the Church, which lead to changes also in the artistic field. The most recent example is the Second Vatican Council. By changing the liturgy, the Council also introduced changes in the design and decoration of new temples. Opening to the new and contemporary was inevitable. This was

8 There is no need to carry out research in this area, because the websites of most archdioceses or dioceses provide links directing us to the 'priests of the diocese' site which provides information on the studies they have completed. 
connected with the adoption of new trends in architecture and required changes in the artistic approach to religious themes.

Such approach was confirmed in 1967 by the Congregation for the Rites, which published the Eucharisticum Misterium - An Instruction on the Worship of the Eucharistic Mystery. It reminds us that care for the setting of liturgical rites should be manifested in the selection of liturgical robes, which 'should serve the task of noble beauty rather than empty splendor' (Acta SS. 1964: 554).

The 1970 edition of the General Introduction to the Roman Missal recommended that attention should be paid to the interior design of the church. It was absolutely necessary to avoid splendor, decorations should be simple, and should reflect the style and needs of modern times (Ogólne wprowadzenie... 1970).

I have only mentioned some of the guidelines in force, which have been provided in the form of legal acts. They give an idea of how experience has been gained over the centuries in the field of the protection of cultural goods and the admission of new art to churches (Codex Iuris... 1984; John Paul II 1988, 1997; Congregation for the Clergy 1971; Wskazania konserwatorskie... 1994).

Summarizing the reflection on the presence of kitsch in contemporary religious art, we ask ourselves the following questions: why does the Church, while taking care of the proper transmission of the truths of faith and seeing the need to use works of art of the highest quality, have such a large number of kitsch buildings, sculptures and paintings? Why, despite the guidelines contained in numerous documents, does it continue to present the sacrum in such a banal and reduced form?

This is probably due to the lack of proper education of priests and lay believers. Mass production, in which real art is degraded to the role of a semi-finished product, is also to blame. Once we realize how widespread the problem is, perhaps we will be able to prevent the flooding of both churches and worshippers' houses with rubbish (Zmarzły 2015).

Of course, it is not about absolutizing art, rather about associating it with culture as a whole, understood in the classical sense. Therefore, if the aim of art and culture, as the ancients used to say, is the 'cultivation'

9 The Latin word 'cultura' comes from colere - 'to cultivate'. As P. Jaroszyński and M.A. Krąpiec (2005: 132) explained: 'The term »cultura" originally meant 
of human reason and the moral perfection of man and the combination of religious content and beauty, then we will deal with real art, art which, while developing man, connects him with God.

\section{Bibliography}

Acta SS. Congregationum (1964), Instructio de cultu mysterii Eucharistici, „Acta Apostolicae Sedis", Vol. 56.

Andrzej Banach (1968), O kiczu, Kraków: Wydawnictwo Literackie.

Imelda Chłodna-Błach (2016), Od paidei do kultury wysokiej. Filozoficznoantropologiczne podstawy sporu o kulture, Lublin: Polskie Towarzystwo św. Tomasza z Akwinu.

Codex Iuris Canonici. Auctoritate Ioannis Pauli PP. II Promulgatus. Kodeks Prawa Kanonicznego (1984), Poznań: Pallotinum.

Congregation for the Clergy (1971), Circular Letter to the Presidents of Bishops' Conferences on the Care for the Historical-Artistic Heritage of the Church, "Acta Apostolicae Sedis", Vol. 63.

farming in ancient Rome. Later, the term »agriculture « was used to describe farming. Early on, starting from Cicero, the term »culture« was used metonymously to denote "animi cultura", which was understood as ennoblement of the human mind, essentially by philosophy: »Cultura animi philosophia est« (Cicero, Tusculanae disputationes, 8 a 11). This understanding of the term "culture « was to a large extent a continuation of what the ancient Greeks called paideia (paidéia), understood as comprehensive "cultivation", the rational upbringing of man, in its individual and social aspects. (...) The perception of order poses questions about its necessary sources and conditions. In the Middle Ages the expression "culture « was associated with religious worship and cult. It was then that commonly used terms came into being: "cultura Christi«, »cultura dolorum«, »cultura christianae religionis« associated with the religious worship of Christ, his Passion, or the Christian religion in general. During the Renaissance, attempts were made to return to the ancient understanding of the term »culture « and to use it to denote the mental and spiritual perfection (or improvement) of man. Therefore, the well-known ancient terms were reintroduced: »animi cultura « and even "georgica animi« - practicing the spirit'. The classical understanding of the word 'culture' denotes that it is the development of man to a full personal life. See also: Chłodna-Błach 2016. 
Dokumenty duszpastersko-liturgiczne Episkopatu Polski (1966-1993) (1994), ed. Cz. Krakowiak, L. Adamowicz, Lublin: Lubelskie Wydawnictwo Archidiecezjalne.

John Paul II (1998), Constitutio Ap. Pastor bonus, „Acta Apostolicae Sedis”, Vol. 88. John Paul II (1997), Sztuka i kultura w służbie ewangelizacji, „L'Osservatore Romano", No. 12.

Piotr Jaroszyński (1986), Metafizyka piękna. Próba rekonstrukcji teorii piękna w filozofii klasycznej, Lublin: Wydawnictwo KUL.

Piotr Jaroszyński (1992), Spór o piękno, Poznań: Wydawnictwo Fonopol.

Piotr Jaroszyński, Mieczysław A. Krępiec (2005), Kultura, [in:] Powszechna encyklopedia filozofii, Vol. 6, ed. A. Maryniarczyk, Lublin: Polskie Towarzystwo św. Tomasza z Akwinu.

Henryk Kiereś (1993), Czy sztuka jest autonomiczna?, Lublin: Wydawnictwo KUL. Henryk Kiereś (1994), Kryzys w sztuce, „Człowiek w Kulturze”, No. 1.

Henryk Kiereś (1996), Spór o sztukę, Lublin: Redakcja Wydawnictw KUL.

Henryk Kiereś (2004), Co zagraża sztuce?, Lublin: Fundacja Servire Veritati Instytut Edukacji Narodowej.

Jan Andrzej Kłoczowski OP (2003), O kiczu w religii i miłości, available online: http://www.katolik.pl/o-kiczu-w-religii-i-milosci,639,416,cz.html.

Ryszard Knapiński (2004), Kicz w kościele, [in:] Sacrum i sztuka. Życie i sztuka, ed. B. Major, J. Matyja, Częstochowa: Wydawnictwo Miejska Galeria Sztuki. Mariusz Leszczyński (2006), Muzea kościelne według aktualnego prawodawstwa Kościoła katolickiego, „Archiwa, Biblioteki i Muzea Kościelne”, Vol. 85.

Mariusz Leszczyński (2008), Ochrona dóbr kultury w świetle aktualnego prawa kościelnego, „Muzealnictwo”, No. 49.

Franciszek Majchrowicz (1922), Historia pedagogii. Ze szczególnem uwzględnieniem dziejów wychowania i szkół w Polsce, Warszawa: Instytut Wydawniczy „Biblioteka Polska”.

Goffredo Mariani (1945), La legislazione ecclesiastica in materia d'arte sacra, Roma: Libreria F. Ferrari.

Sacrosanctum concilium (1964), „Acta Apostolicae Sedis”, Vol. 56.

Danuta Mikeska (2008), Kicz w filmie postmodernistycznym, „Czasopismo Filozoficzne", No. 3.

Andrzej Osęka (1978), Wstęp, [in:] Abraham Moles, Kicz, czyli sztuka szczęścia, transl. E. Wende, A. Szczepańska, Warszawa: PIW. 
Ogólne wprowadzenie do Mszału Rzymskiego (Missale Romanum - editio typica 1970) (1971), „Ruch Biblijny i Liturgiczny”, No. 1.

Lucyna Rożek ed. (2000) Kicz, tandeta, jarmarczność, Częstochowa: Wydawnictwo WSP.

Second Vatican Council (1963), Constitution on the Sacred Liturgy Sacrosantum Concilium, available on-line: http://www.vatican.va/archive/hist_councils/ ii_vatican_council/documents/vat-ii_const_19631204_sacrosanctumconcilium_en.html.

Beata Skrzydlewska (1997), Ochrona zabytków sztuki na podstawie dokumentów kościelnych, „Archiwa, Biblioteki i Muzea Kościelne”, Vol. 67.

Beata Skrzydlewska (2002), Uregulowania prawne Kościoła rzymskokatolickiego dotyczące ochrony zabytków, „Archiwa, Biblioteki i Muzea Kościelne”, Vol. 77. Tomasz Zmarzły (2015), Kicz - znaczy udawany, available on-line: http://www. niedziela.pl/artykul/119426/nd/Kicz-\%E2\%80\%93-znaczy-udawany.

\section{Internet sources}

http://www.targikielce.pl/pl/sacroexpo.htm.

\section{Summary}

The study is the attempt to identify the sources of the kitsch phenomenon in contemporary religious art in Poland. The main subject of the study regards church interiors, particularly art works present in the sacred spaces of the Catholic church in Poland. The analysis, which does not include the notion of kitsch or other aspects of this problem, will be presented from the point of view of a person who has been scientifically and practically engaged in the protection of religious art monuments for years. Observations made during the implementation of projects for church museums, providing advice on the monument protection, as well as didactic work as a lecturer of art history in clerical seminaries prompted me to reflect on the level of Polish sacred art and its significance for the reception of the message of the Church.

Keywords: kitsch, art history, aesthetics, religious art, sacred interiors, interior design, contemporary religious space 